\title{
Strategies for Selecting Membrane Protein-Specific Antibodies using Phage Display with Cell-Based Panning
}

\author{
Mohamed A. Alfaleh 1,2,* (1), Martina L. Jones 1,3,* (D), Christopher B. Howard 1,3,4 \\ and Stephen M. Mahler ${ }^{1,3}$ \\ 1 Australian Institute for Bioengineering and Nanotechnology (AIBN), The University of Queensland, \\ Brisbane, Queensland 4072, Australia; c.howard2@uq.edu.au (C.B.H.); s.mahler@eng.uq.edu.au (S.M.M) \\ 2 Faculty of Pharmacy, King Abdulaziz University, Jeddah 21589, Saudi Arabia \\ 3 Australian Research Council Training Centre for Biopharmaceutical Innovation, \\ The University of Queensland, Brisbane, Queensland 4072, Australia \\ 4 Centre for Advanced Imaging, The University of Queensland, Brisbane, Queensland 4072, Australia \\ * Correspondence: mohamed.alfaleh@uqconnect.edu.au (M.A.A.); martina.jones@uq.edu.au (M.L.J.); \\ Tel.: +61-733-463-178 (M.L.J.)
}

Academic Editor: Dimiter S. Dimitrov

Received: 14 June 2017; Accepted: 7 July 2017; Published: 5 August 2017

\begin{abstract}
Membrane proteins are attractive targets for monoclonal antibody (mAb) discovery and development. Although several approved $\mathrm{mAbs}$ against membrane proteins have been isolated from phage antibody libraries, the process is challenging, as it requires the presentation of a correctly folded protein to screen the antibody library. Cell-based panning could represent the optimal method for antibody discovery against membrane proteins, since it allows for presentation in their natural conformation along with the appropriate post-translational modifications. Nevertheless, screening antibodies against a desired antigen, within a selected cell line, may be difficult due to the abundance of irrelevant organic molecules, which can potentially obscure the antigen of interest. This review will provide a comprehensive overview of the different cell-based phage panning strategies, with an emphasis placed on the optimisation of four critical panning conditions: cell surface antigen presentation, non-specific binding events, incubation time, and temperature and recovery of phage binders.
\end{abstract}

Keywords: affinity selection; antibodies; cell markers; cell receptors; competitive elution; epitopes; panning; phage display; transfection; whole cell

\section{Monoclonal Antibodies}

Monoclonal antibodies (mAbs) are biological macromolecules derived from B-lymphocytes. The specificity and high affinity of a mAb towards a particular target makes them attractive drug candidates within the biopharmaceutical industry. Their success as therapeutic entities is due to their proven efficacy in targeted therapy, ability to be structurally modified and relatively low toxicity profile in relation to other small molecule pharmaceuticals [1,2]. To date, more than $40 \mathrm{mAbs}$ have been approved for clinical applications and many more are under clinical and pre-clinical investigation $[3,4]$.

\subsection{Generation of Monoclonal Antibodies Using Hybridoma Technology}

Monoclonal antibodies were first produced using hybridoma technology in which an immortal myeloma cell is fused with an antibody-producing spleen cell of an immunized animal $[5,6]$. Although revolutionary and still commonly used to produce antibodies as research reagents, clinical applications 
of murine-derived $\mathrm{mAbs}$ have limited therapeutic efficacy due to the immune response that is mounted against these $\mathrm{mAbs}$ by the patient. Antibody engineering techniques were subsequently utilised to create chimeric or humanized antibodies by utilising the murine variable regions or complementary determining regions, respectively, in conjunction with human constant regions, in order to reduce the human anti-mouse antibody response (HAMA) [7-9]. Fully human antibodies are now generated using the same hybridoma technology in transgenic mice that have human immunoglobulin loci [10]. Antibody phage display is an alternative technique for generation of monoclonal antibodies, whereby antibodies can be isolated from large immunoglobulin gene repertoires [11] rapidly in a matter of weeks.

\subsection{Generation of Monoclonal Antibodies Using Phage Display Technology}

Phage display, first described by George P. Smith in 1985, is a powerful tool for displaying proteins or peptides of interest on filamentous phage through fusion with a viral coat protein [12]. Each phage clone within an antibody phage library displays an exclusive antigen-binding site, made up of random combinations of heavy and light chain variable fragments cloned from pools of B-cells [13]. Several binding entities such as variable domain ( $\mathrm{Fv}$; variable regions of the heavy $(\mathrm{VH})$ or variable regions of the light chain (VL)), single-chain variable domain ( $\mathrm{scFv}$ ), fragment antigen binding (Fab) or peptides that might serve as novel therapeutics have been isolated from phage display libraries [14-18]. Antibody phage libraries are constructed from mRNA extract from natural sources, such as bone marrow, peripheral lymphocytes or the spleen $[19,20]$, which can be either immunized [21,22] or naïve [23]. Alternatively, phage libraries could be synthetic in order to enhance the antibodies' characteristics or to make a large and highly diverse phage repertoire. Creating combinatorial antibody libraries on filamentous phage have been achieved through combined populations of $\mathrm{VH}$ - and VL-domains which are joined by a flexible protease-resistant glycine-serine linker (Gly4Ser) 3 into a single DNA sequence [14]. Monovalent display is the most popular display system because it allows for selection of higher affinity antibodies [24-27].

Antibody display also includes other newer technologies such as yeast and mammalian display. Wittrup and Boder were the first to describe the yeast surface display system when they fused scFv antibody fragments to the C-terminus of the binding subunit of Saccharomyces cerevisiae a-agglutinin receptor (Aga2p) [28]. Since then, different yeast antibody libraries were constructed to display full-length antibodies as well as antibody fragments such as scFvs and fragment antigen-binding region (Fabs) [28-30]. Several antibodies have also been successfully isolated against different targets through yeast display [31-34]. Additionally, mammalian cells have been used to display scFv or whole Immunoglobulin Gs (IgGs) [35-40], allowing isolation of high affinity antibodies with specific biological functions [37,38]. Each display system has its advantages and disadvantages, however, determining those are beyond the scope of this review. Here, we will instead focus on the most popular type of antibody display, the phage display.

In phage display, filamentous phage strains such as M13, f1 and fd are the most commonly used types of phage, since they are stable, easy to manipulate and capable of keeping the infected cells intact during their life cycle [41-44]. Filamentous phage is a flexible cylindrical shaped virus particle that consists of circular single-stranded DNA (6407-base), coated with five different coat proteins (pIII, pVIII, pVI, pVII and pIX) [45,46]. Although all the aforementioned coat proteins can be fused with a product to construct phage display libraries, pIII-fused products are the most commonly used. The pIII is able to display large protein sequences such as scFv and Fab $[44,47,48]$, and the crystal structure of pIII shows that it is willing to accept peptide or protein without losing its function, due to the structural flexibility [49].

There are more than 100,000 publications and 80,000 patents related to phage display documented in the three decades since Smith's seminal report in 1985 [50]. Some blockbuster drugs, with annual sales beyond US\$1 billion, such as Lucentis and Humira, have been isolated using phage display [51]. The latter is considered the highest selling drug globally, with total sales of US $\$ 11$ billion since it was 
launched in 2002 [51]. Now, approximately 35\% of mAbs in clinical trials are derived from phage display, which means phage display will remain a prominent platform technology for $\mathrm{mAb}$ discovery in the biologics industry [50,51].

Panning (also called biopanning) or affinity enrichment is a technique for the isolation of antibody fragments from a phage library based on their binding affinity to a given target [52]. The general procedure includes three major steps used for selection: (i) exposing the library to the desired target and capturing specific phage binders; (ii) washing to eliminate non-selective or low affinity binders; and (iii) eluting the specific binders and amplification of the recovered phage. This process is usually repeated in an iterative manner three to six times, in which the diversity of phage is reduced while the proportion of selective strong affinity binders to the target is increased [53-55]. Although it is a fairly straightforward technique, there are many factors that can influence the overall outcome, such as library quality, nature of the target, binding affinity, change of $\mathrm{pH}$ and other environmental conditions, and availability of the desired binder within the library. One of the most important factors to consider is how to present the antigen to the library to ensure it is displayed in its correct conformation. Direct immobilisation of purified antigen onto plastic is the most common method, but this may result in conformational changes of the target antigen. Other methods include solution-based panning using biotinylated antigens [56] or calmodulin binding peptide-tagged antigen [57] or panning on the surface of whole cells. Cell-based panning allows the antigens to sustain their natural conformation, this ensuring the isolated binders are able to access epitopes in vivo. Cell-based panning may be used to identify new cell biomarkers by isolating antibodies which can discriminate between different cellular states, or it can allow antibody isolation even when the antigen of interest in not available in pure form [58].

\section{Whole Cell-Based Phage Display: A Monoclonal Antibody Discovery Platform for Membrane Proteins}

Membrane proteins (e.g., G protein-coupled receptors, ligand-gated ion channels, receptor tyrosine kinases and immunoglobulin-like receptors) are desirable targets for phage display in order to obtain novel $\mathrm{mAbs}$ for research, diagnostic and therapeutic purposes. They are a large group of proteins that play key roles in transportation and signal transduction, and account for 20 to $30 \%$ of all proteins in most living entities [59,60]. In diseases such as cancer, some membrane receptors change their normal activity levels, for instance, overexpression of human epidermal growth factor receptor 2 (Her2) in breast cancer [61] and Mesothelin in malignant pleural mesothelioma [62]. Membrane receptors represent $44 \%$ of human drug targets, which make them the largest group of drug targets [63,64].

Despite huge advancements in protein engineering and manufacturing, expression of membrane proteins in a soluble form and subsequent purification are still challenging and time-consuming. For some membrane proteins, it is simple to purify just the extracellular domain and successfully obtain antibodies using panning on immobilised protein [65-68]. However, many membrane proteins, such as ion channels, do not have a large extracellular domain that can be purified. Expressing these membrane proteins in large amounts is difficult and, outside of the hydrophobic environment of the cell membrane, these proteins can undergo conformational changes and/or aggregation. For instance, the expressed full-length soluble membrane proteins, such as the large family of the 7-transmembrane (7-TM) G-protein-coupled receptors, which represent $12 \%$ of drugs targeting receptors [64], lack appropriate post-translational modifications and are poorly soluble in an aqueous media, because they contain complex structures that are not properly formed during recombinant expression [69]. They can easily form aggregates, lose their natural conformational structures and tend to denature when coated on solid surfaces. This means they become structurally different from what exists in nature [70-72], which consequently might lead to isolating binders that do not identify the antigen in its native form. Such binders might identify epitopes that could be masked or not exposed naturally and therefore not accessible on the antigen's native conformational structure [73,74]. Different membrane protein presentation methods to overcome these issues have been reviewed by Huang et al. [75]; however, 
here we will focus on the various attempts to optimise whole cells displaying the antigen of interest, using native cells or engineered cell lines, to ensure the correct conformational structure, in a process called cell-based panning.

Screening antibody libraries against membrane proteins in their native or even near-native conformations using whole-cells or tissue to isolate mAbs might result in more biologically relevant antibodies which depend on binding to a specific antigenic determinant that is naturally exposed on the targeted protein [76-78]. Cell-based panning has many advantages over purified protein panning, since it can be employed to retrieve antibody clones that are specific for either known or unknown antigens that are present on the surface of specific cell populations; also it can be employed in case of unavailability of the targeted antigen in pure form [58,79-81].

Panning on a transfected cell line permits selection of antibodies to cell bound proteins without the need for purification of the desired protein, which as a result accelerates the generation of antibodies dramatically. This was evident in attempts to obtain binders to innate immunity receptor Toll-like receptor 2 (TLR2), a large complex membrane protein with a large extracellular domain [74]. The researchers used both standard soluble antigen-based and cell-based panning protocols on transfected cells in parallel for comparison purposes. None of the isolated clones obtained from the purified, recombinant protein strategy were able to bind the receptor in its native state on the cell surface. On the other hand, eight unique phage-derived binders from panning an immune library on transfected cells were able to bind TLR2 in its native structure.

Phage display panning can be also performed on yeast cells expressing the membrane bound protein on their cell surfaces. For instance, a high throughput approach was reported for generating several $\mathrm{mAbs}$ from a scFv antibody library against multiple different types of membrane proteins displayed on yeast surface [82]. Additionally, panning on yeast cells can be performed in combination with panning on mammalian cells, having both cell types expressing the same antigen of interest to enhance the selection process by directing the antibody-phage binders toward the targeted antigen [83]. Several specific antibodies were isolated after panning a $\mathrm{scFv}$ phage library against a breast cancer cell line overexpressing cell surface adhesion receptor (CD44) and ephrin type-A receptor 2 (EphA2) antigens for two rounds before panning the retrieved polyclonal phage pool on yeast expressing domain 1 of CD44 and the extracellular domain of EphA2 for another two rounds.

Despite the advantage of not requiring purified antigens, there are many difficulties associated with whole cell panning including low receptor density, high background of irrelevant antigens and non-specific adsorption of phage particles. Therefore, optimisation of the cell-surface antigen presentation, washing procedures, phage recovery and incubation conditions can contribute to a successful cell-based panning strategy.

\section{Optimisation of Strategies for Phage Display with Cell-Based Panning}

\subsection{Optimising Cell Surface Antigen Presentation}

The first and the most critical step in any cell-based panning method is the appropriate exposure of target antigen on the cell surface. Native cells can be used as an antigen source; for example, cancer cells can be incubated with a library that has first been depleted against the equivalent non-cancerous cells to identify novel cancer-specific reagents. However, native cells usually have relatively low expression levels of desired antigens which make it difficult to capture even high-affinity clones from a highly diverse library. In addition, assessing the optimal culturing conditions for native cells prior to panning is crucial to achieve higher antigen density on the cell surface. For instance, some native cell lines showed a drastic enrichment of certain cells markers when they grew under non-adherent sphere-forming culture conditions compared to traditional monolayer culture [84]. For known antigens, transfection and expression of recombinant protein on the cell surface allows for a higher antigen density. Examples of transfected cell pannings include stable transfection, (e.g., tetraspanin cell surface glycoprotein CD9 [85], müllerian inhibiting substance type II receptor (MISIIR) [86] and TLR2 [74]) 
and transient transfection, (e.g., canine tyrosine-protein kinase receptor CD117 (c-Kit), human CD83 and bat CD11b) [87].

Many studies show the ability to isolate unique binders after panning phage libraries against either confluent attached monolayers [88-90] or against cells in suspension [85,91]. However, in the case of CD146 and CD36 targets, successful isolation of binders was only achieved when the phage libraries were biopanned against cell lines in suspension rather than on monolayers [92,93]. Reportedly, the binders isolated from panning on confluent monolayers were specific to the culture flask plastic surface and the serum protein within the culture medium. Suspension culture has the additional advantage of a greater available surface area for target membrane protein presentation.

Eisenhardt et al. described a cell suspension-based panning strategy for the selection of scFv-binders to a specific conformational state of a cell surface receptor (Figure 1) [94]. This protocol allows for isolation of $\mathrm{scFv}$-antibodies against conformation-specific neo-epitopes that are exposed only after physiological alterations, which activated the receptors (platelet integrin $\alpha \mathrm{Ilb} \beta 3$ (also known as Glycoprotein IIb/IIIa) and Macrophage-1 (Mac-1)) [95-97]. Briefly, this protocol involves firstly depleting the library on non-activated cells, then transferring the unbound phage to an activated cell suspension expressing the targeted receptors in their activated conformation. They also used a native cell line in the first round, and then changed to recombinant cells expressing the same receptor to reduce the non-specific binding background and improve the selection process.

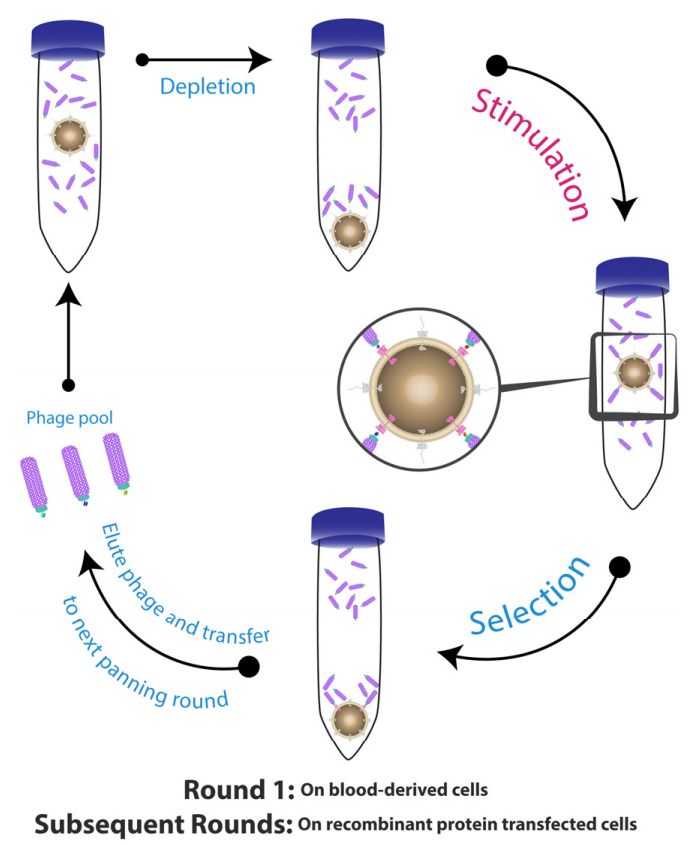

Figure 1. Selection of conformation-specific single-chain variable domain (scFv)-phage. The process of the panning started with depleting the scFv-phage library on non-activated cells having unwanted and non-stimulated epitopes. The non-specific scFv-phage/non-activated cell complex were centrifuged and discarded, while the supernatant containing the free scFv-phage were transferred into physiologically stimulated cells expressing neo-epitopes in their active conformational structure. The $\mathrm{scFv}$-phage/activated cell complexes were centrifuged and the bound scFv-phage were both eluted with low $\mathrm{pH}$ or by competition with ligand, and collected for the subsequent panning rounds. Figure shows methodology described by Eisenhardt et al. [94].

In the panning strategies described above, relatively large numbers of cells (between $10^{5}$ and $10^{7}$ ), are required to provide sufficient display of the target antigen to the library. However, obtaining such large cell numbers can be impractical for native tissue, where only limited material from the patients 
may be available. A microfluidic technology or a microselection strategy can be applied to bypass the need for high cell numbers during the panning process.

A microfluidic phage selection approach offers a controlled, continuous fluid flow of phage-displayed peptides over live, adherent cells within a microfluidic chamber. This allows for both a high ratio of phage particles to cells, and a means for high stringency washing without cell loss [98]. Dorfmueller et al. [99] used the aforementioned microfluidic device to isolate phage-displayed antibodies against unknown cell surface markers that express in human corneal endothelial cells (hCECs). They successfully isolated a scFv specific to the hCECs layer and by integrating immunoprecipitation and mass spectrometry, they were able to identify immunoglobulin-like protein ALCAM (CD166) as a marker for hCECs. Microfluidics also offers a unique platform for automating the selection process, achieving high-throughput selection [100] and providing a robust continuous washing system that markedly reduces the rebinding events [101,102]. However, microfluidic channels are known for their ability to induce shear stress, which in some cell types can alter their physiological nature due to their sensitivity, such as endothelial cells [103,104].

Microselection or shadow-stick selection is an exceptional method that is able to retrieve unique binders by applying the phage library against rare cells within a heterogeneous solution (Figure 2) $[105,106]$. Sørensen et al. conducted the microselection by fixing the cell suspension sample onto a specific glass slide, with the rare cell marked according to its distinct morphology or by immunostaining if specific biomarkers are known. This is followed by application of a scFv-phage library and subsequent washing steps. The unique cell was relocated and shielded with a minute flat gold disc attached to a glass pipette "shadow stick" before inactivating all the unshielded phage with ultraviolet (UV) irradiation. The only viable phage remaining were those bound to the target cell; these were then eluted and amplified. This method can help to identify novel biomarkers that are present on these rare cells. Microselection to isolate antibodies specific for very rare cell types, has potential for enhancing current diagnostic procedures, since currently unique cells types such as circulating tumour cells, are very difficult to detect due to their very low percentage in patients' peripheral blood [107].

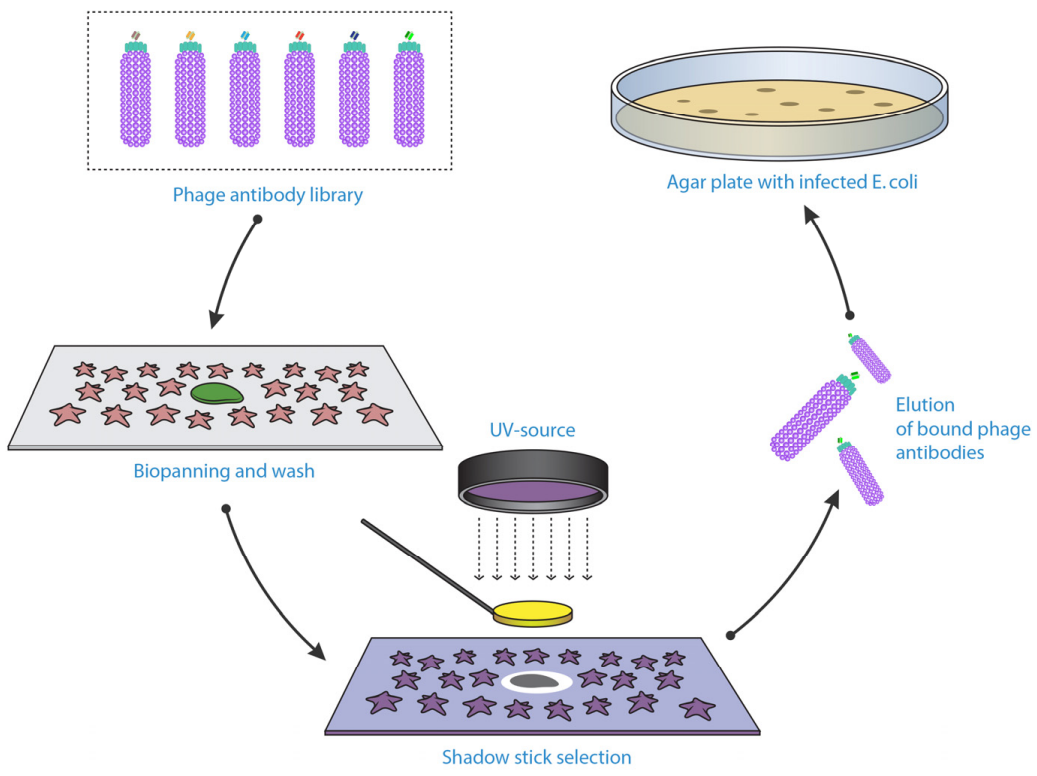

Figure 2. Isolating phage antibody binders against a single rare cell using shadow-stick selection technique. Cells placed on glass slide, with the targeted cell marked. Shadow-stick (minute flat gold disc attached to a glass pipette) placed on top of the targeted cell to protect the phage bound to it, before killing the unprotected phage with ultraviolet (UV) irradiation. Figure shows methodology adapted from Sanchez-Martin et al. [108]. 
Even in a seemingly optimised cell-based panning method, the nature of the antigen highly influences the likelihood of success. Hoogenboom et al. performed identical cell based panning procedures on two different human receptors, somatostatin and CD36 expressed on Chinese hamster ovary $(\mathrm{CHO})$ cells, in an attempt to isolate antibodies that are able to bind epitopes within their extracellular domains [93]. They were unable to isolate any somatostatin receptor-specific phage clones even when using ligand-competitive elution. Somatostatins have short, heavily glycosylated extracellular loops of $\sim 40$ amino acids and have low immunogenicity, which make them challenging targets $[93,109]$. On the other hand, they were successful in isolating antibodies against CD36, which is characterised by its large, highly glycosylated immunogenic extracellular domain, which proved to be a straightforward target for cell based panning [93,110]. Jones et al. [87] also alluded to the success of cell-based phage panning being very antigen-dependent, having achieved greater success with large elongated receptor CD117 compared with shorter compact CD11b. These results confirm that the nature and the accessibility of the targeted membrane-bound receptors can determine the cell-based panning outcomes.

\subsection{Reducing Non-Specific Binding Events}

The approach of panning on whole cells or tissue is a notoriously tedious process. Antigens in their natural conformation are complex and exist at lower concentrations on the cell surface as compared to the rest of the host cell proteins, and the phage are therefore exposed to a population of antigens which are mostly irrelevant, both on the inside and the outside of the cell. The ultimate goal therefore is to enhance the selection efficiency of mAbs identifying only the desired surface antigens against a background of irrelevant antigens.

The use of blocking agents, such as Bovine Serum Albumin (BSA), milk and casein is a common practise in phage display to block the non-specific sites and thereby prevent the non-specific binding events [111,112]. However, in cell-based phage display, it is also critical to deplete the library of binders to other non-relevant cell-surface antigens by exposing the library on a similar cell line which is negative for the desired antigen, prior to the positive cell line [88,91,113-115]. If possible, alternating cell lines expressing the same target antigen can help to eliminate any irrelevant binders that are enriched in the first round (Figure 3) [87]. This strategy is possible when using transfected cells, as the host cell can easily be changed each round. Alternatively, switching the panning each round between latex beads coated with the purified form the antigen and cells expressing the same antigen, would enhance the selection procedure [116]. 


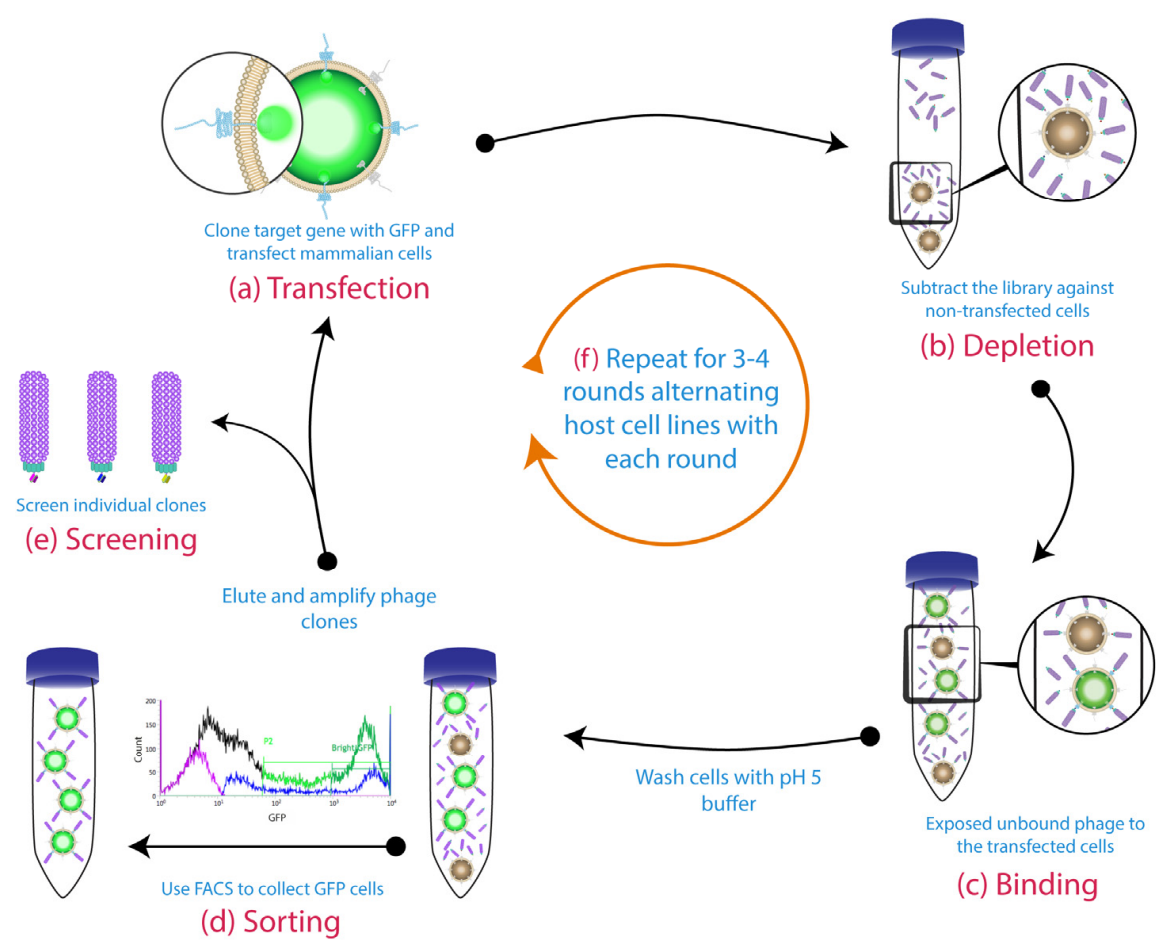

Figure 3. Cell-based panning protocol using GFP-sorting and alternative host cell lines: (a) The gene for the target membrane protein was cloned in-frame with GFP to be expressed on the cell surface. (b) The phage library was subtracted on untransfected cells. (c) Then, the free phage were panned against transiently transfected cells. A pH 5 wash step was conducted before the fluorescence-activated cell sorting method (FACS) sorting (d). The binders from the sorted cells were eluted with a low $\mathrm{pH}$ buffer. These binders were then amplified for the subsequent rounds and individual clones were screened by the end of biopanning campaigns (e). (f) The host cell line was alternated each round (1st round: Chinese hamster ovary (CHO) cells, 2nd round: human embryonic kidney 293 cells (HEK293), etc.). Figure shows methodology described by Jones et al. [87].

A cell suspension used for panning contains not only the fully intact healthy cells that express the antigen of interest, but it also contains dead cells, cell debris and cells that do not express the targeted protein on their surfaces, which can often lead to isolation of non-specific binders. De Kruif et al. was the first to report a subtractive process to rapidly isolate phage-derived binders against B-cell specific markers in their native conformation, by incorporating a fluorescence-activated cell sorting method (FACS) using anti-CD3 and anti-CD20 fluorochrome-labelled antibodies to separate subpopulations of T lymphocytes (CD3+) and B lymphocytes (CD20+) from peripheral blood cells [117].

However, this sorting method is unable to distinguish between cells harbouring the desired tumour-associated antigens from others within the same cell subpopulation, which might result in isolation of undesirable binder candidates. This issue has been overcome by incorporating detectable tags into the target antigen. For example, cells expressing human Müllerian inhibiting substance type II receptor (MIS-IIR) tagged with Hemagglutinin (HA) (detectable with fluorescein-conjugated anti-HA antibody) or canine CD117 fused with green fluorescent protein (GFP) can be isolated by FACS from a cell mixture after incubation with a phage library (Figure 3) [86,87]. Accordingly, several anti-MISIIR and anti-CD117 scFv clones were successfully isolated from the sorted antigen-expressing cells. According to Poul, typical cell-based panning strategies result in 1-12 phage bound per cell [115]. Using this modified-FACS technique resulted in two phage bound per cell after three rounds, which mean specific binders with less background of non-specific binders [86].

Another study described an effective method that dramatically improves the selection of antibodies against cell surface antigens rather than intracellular antigens by eliminating the dead 
cells and cell debris from the cell suspension before each panning round [118]. It was achieved by incubating breast carcinoma cell (MCF7) with biotinylated Annexin V, which binds to the intracellular phospholipid membrane phosphatidylserine when it is translocated to the cell surface in dead or dying cells [119]. The biotinylated Annexin V bound cells were then captured by streptavidin linked to Dynabeads (superparamagnetic spherical polymer particles) $[118,120,121]$ to remove dead cells and cell debris. As a result, the phage library was exposed only to live cells, ensuring that the isolated phage will bind to antigens on the cell surface.

The non-specific background not only includes the undesirable cellular compartments and irrelevant cell-surface antigens, but also the phage that are non-specifically adhered to the cell surfaces via interaction with the phage coat proteins. These phage will be propagated along with the specific phage making enrichment of the correct clones difficult. Amongst the non-specifically bound phage will be a considerable population of phage which are not displaying an antibody fragment, due to insert-free phagemid vectors being present in the library [122,123]. Insert-free vectors arise from the incomplete restriction and/or re-ligation of the phagemid during antibody phage library cloning. Insert-free phage will have a growth advantage during phage amplification as they are not expressing the scFv-g3p fusion protein, and therefore they become enriched over several rounds of panning [122-124]. Two methods have been established to address the problem of non-specific adherence of phage to cell surfaces. Firstly, the interaction of phage with cell surfaces via coat proteins can be reduced by $75 \%$ by conjugating polyethylene glycol (PEG) polymers to the phage particles [125]. This creates a hydration sphere reducing non-specific interaction. Secondly, non-specifically adhered phage can be removed by incorporating a low $\mathrm{pH}$ buffer ( $\mathrm{pH}$ 5.0) into the washing steps [124]. Removal of non-specific phage was demonstrated by showing that the enrichment of insert-free phage was prevented when this wash was incorporated [124].

One of the most critical drawbacks of panning methodology is the repeated washing and centrifugation steps required to remove non-specifically bound phage. In some cases, it can be up to 10 times per round [90], which might lead to loss or lysis of cells, especially in the presence of surfactant such as Tween-20 in the washing buffer. Optimised washing conditions have not been fully investigated and there are few studies addressing this particular issue. A technique known as BRASIL (Biopanning and Rapid Analysis of Selective Interactive Ligands) has been developed by Giordano et al. [126] and utilised successfully by Lipes et al. [74] and Carneiro et al. [127], eliminating the need for multiple washing steps (Figure 4). BRASIL is a simple, sensitive, single-centrifugation step that separates phage-cell complexes from unbound phage by differential centrifugation. This is achieved by adding a non-miscible organic solvent, to the aqueous cell-phage suspension. After centrifugation, two separate phases are formed; the cells with bound phage form a pellet in the non-miscible lower hydrophobic phase, while the upper hydrophilic phase contains the unbound phage. Centrifuging the cells through the non-polar solution has the additional advantage of effectively removing any loosely bound phage. Nevertheless, it cannot guarantee the complete removal of undesirable specific phage/antigen binding because the cell pellet within the organic phase also contains unwanted cellular compartments. 


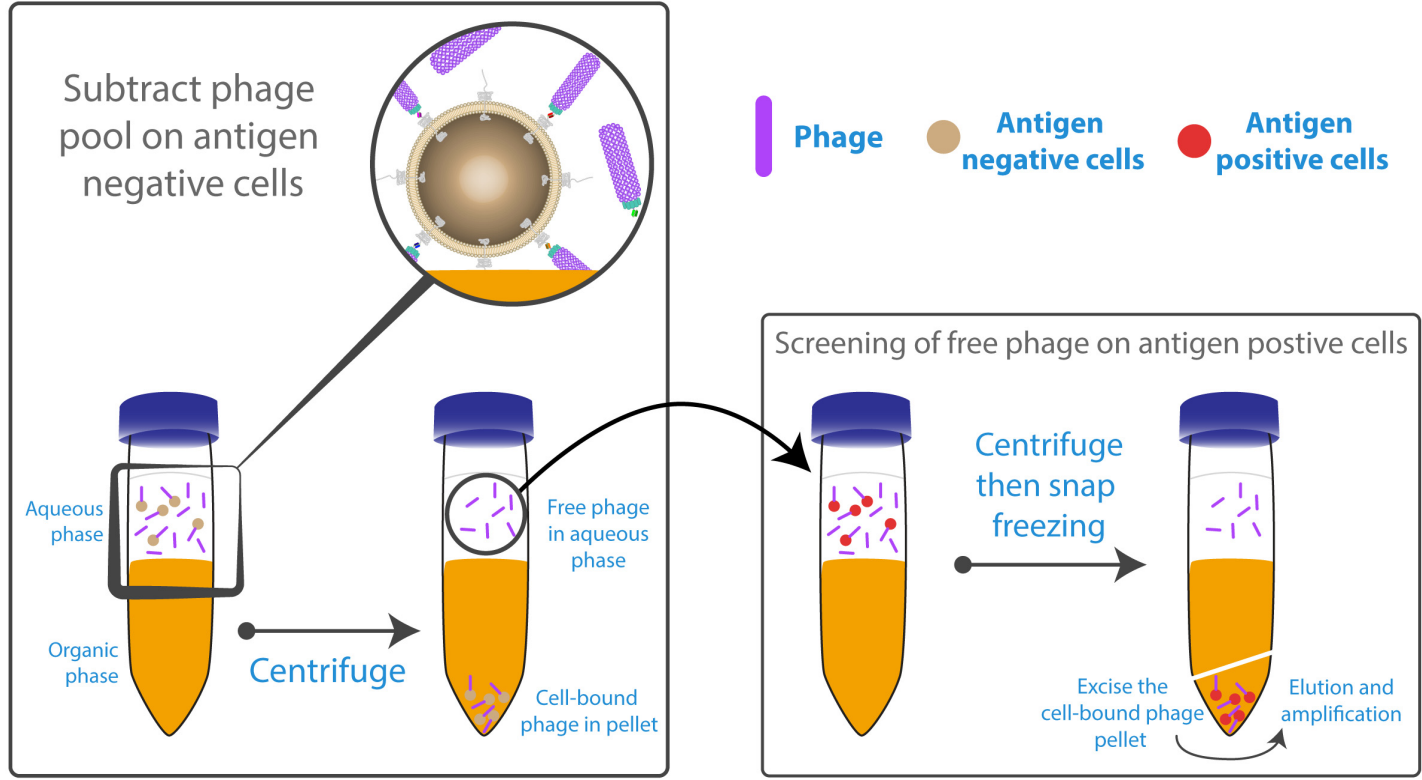

Figure 4. Whole cell-based panning using Biopanning and Rapid Analysis of Selective Interactive Ligands (BRASIL). Panning started with a depletion step for the phage library on cells not expressing the antigen of interest. The phage/unwanted cells complex were centrifuged into the organic phase. Free phage within the aqueous supernatant are transferred and incubated with cells expressing the antigen of interest into the aqueous solution before centrifugation through the organic phase. Bound phage were rescued from the organic phase, and then amplified to be used for the subsequent panning rounds. Figure shows methodology described by Giordano et al. [126].

\subsection{Optimising Incubation Time and Temperature}

Temperature and incubation time can affect the kinetic properties of antibodies during the selection process. For instance, in an experiment to obtain antibodies against Chlamydophila psittaci (C. psittaci), no binders were isolated when the panning was performed at $4{ }^{\circ} \mathrm{C}$, but enrichment of binders was observed when the panning was performed at $37^{\circ} \mathrm{C}$ [128]. However, most of the published protocols recommend performing the selection step at $4{ }^{\circ} \mathrm{C}$ for $2-16 \mathrm{~h}$ (less incubation time is recommended) for membrane receptors, because at low temperature the receptor-mediated internalization is remarkably reduced and the cells become desensitized to environmental stimuli $[74,101,103,126,129]$. However, unique phage-derived clones against membrane proteins have also been retrieved after incubating phage libraries with cells at $20^{\circ} \mathrm{C}$ or $37^{\circ} \mathrm{C}$ for $1-20 \mathrm{~h}[90,91,93]$. In some cases, incubation at $4{ }^{\circ} \mathrm{C}$ might cause receptor clustering or unspecific cell activation, and might also hinder the expression of specific epitopes [94]. If it is necessary to perform the incubation step at room temperature, a short incubation period $(2 \mathrm{~h})$ is recommended to reduce the internalization rate [94].

In other cases, it is desirable to isolate antibodies that can internalize, to allow receptor-mediated endocytosis for targeted drug delivery. Poul et al. [115] and Fitting et al. [130], conducted panning using both $4{ }^{\circ} \mathrm{C}$ and $37^{\circ} \mathrm{C}$ to isolate tumour specific antibodies that can be internalized (Figure 5). All the steps dedicated to remove the non-specific and weakly bound phage were performed at $4{ }^{\circ} \mathrm{C}$ to prevent receptor mediated internalization, followed by an incubation step at $37{ }^{\circ} \mathrm{C}$ for $15 \mathrm{~min}$ to stimulate surface-bound phage endocytosis. Reducing the incubation temperature to $4{ }^{\circ} \mathrm{C}$ after the short 37 ${ }^{\circ} \mathrm{C}$ incubation is crucial to avoid the degradation of endocytosed phage within the lysosome [131]. After removing the remaining surface bound phage by low $\mathrm{pH}$ elution, the internalized phage can then be retrieved from the cell lysate. 


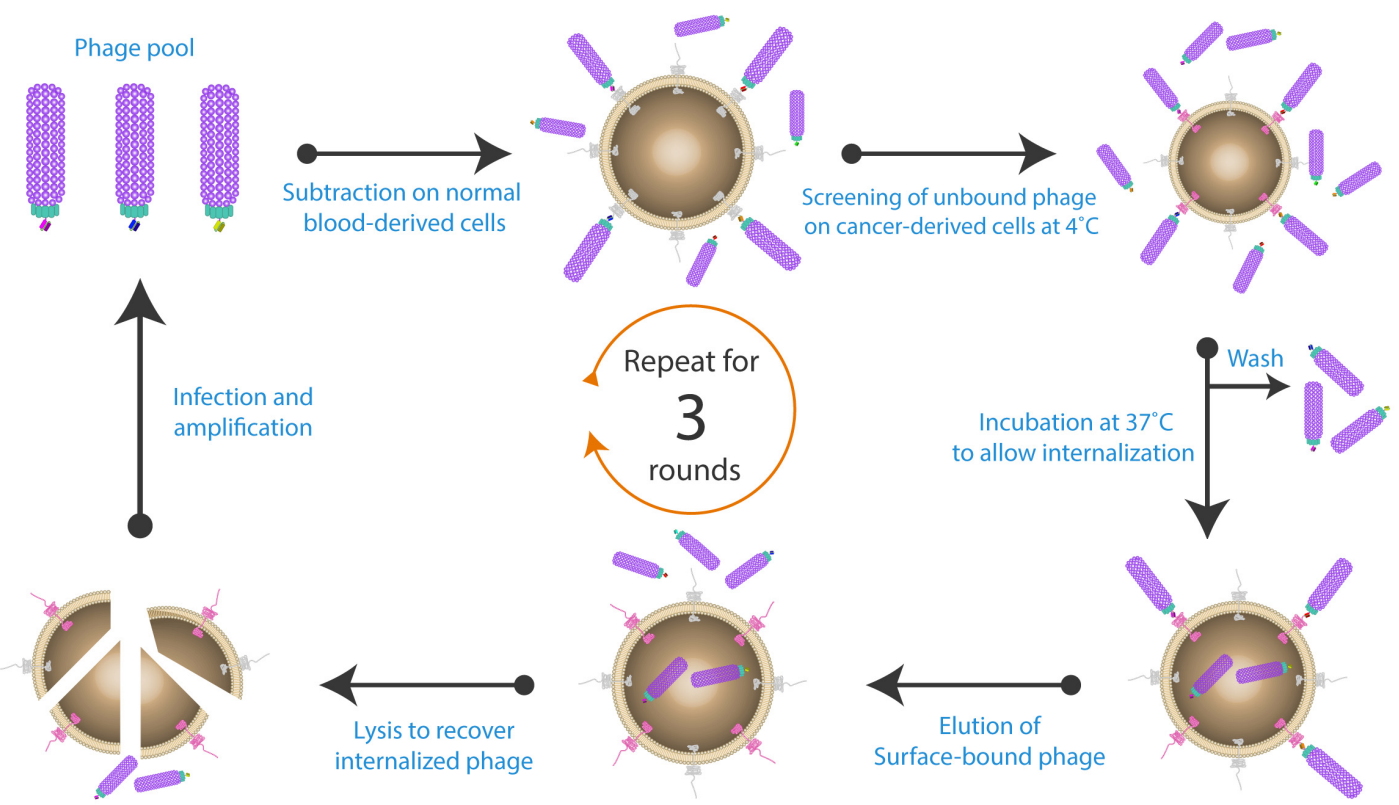

Figure 5. Isolation of specific internalizing antibodies by phage display. The antibody-phage library was initially subtracted on healthy cells, and then the free phage were screened on cells harbouring the antigen of interest. A washing step was performed to remove all the non-specific and unbound phage. All the previous steps were conducted at $4{ }^{\circ} \mathrm{C}$. The cells were then incubated at $37^{\circ} \mathrm{C}$ to induce phage internalization. Cell surface bound phage were removed by low $\mathrm{pH}$ elution buffer, while the internalized phage were retrieved by cell lysis. The isolated phage particles were then amplified and used for subsequent panning rounds. Figure shows methodology described by Fitting et al. [130].

$\mathrm{pH}$-sensitive dyes are only fluorescent when they internalize into biologically relevant low $\mathrm{pH}$ environments such as the intracellular compartment of the cell or in the intisticial space of the tumour [132-134]. Weissleder et al., were able to bioconjugate wild type filamentous bacteriophage with a water-soluble $\mathrm{pH}$-sensitive dye that is fluorescent in acidic environments and non-fluorescent at neutral or basic $\mathrm{pH}$ [133]. Therefore, this approach can be employed on filamentous phage displaying antibody variable domains to obtain fluorescence-based images after panning on whole cells to identify the internalised binders. This technique can be utilised to adjust the required time of internalization during the incubation step at $37^{\circ} \mathrm{C}$ and consequently determine the optimum duration of incubation.

\subsection{Improving Phage Recovery}

Usually, cell-bound phage are eluted by using a low $\mathrm{pH}$ buffer $[90,91]$. However, some studies indicate that acidic $\mathrm{pH}$ is not sufficient and a significant portion of phage still remain intact with the cell pellet after centrifugation [92,93]. Alternately, using an alkaline solution or direct infection of cell-bound phage with logarithmically growing E. coli might be reasonable alternatives for better phage recovery $[74,92,93,126]$. Other studies indicate that a significant portion of phage is internalized into the cells post-binding to cell surface antigens, so combining the low $\mathrm{pH}$ solution with or without non-denaturing detergents (e.g., NP-40 or Tween 20) will enhance the phage recovery, drastically $[135,136]$. These type of detergents can lyse the cells without affecting the natural structural configurations of the proteins [137].

Some protocols use a competitive elution strategy by using known physiological ligands or specific blockers to displace the bound phage. For example, Eisenhardt et al. used a range of competitive binders such as eptifibatide and abciximab for GPIIb/IIIa, or even known biological ligands such as fibrinogen for GPIIb/IIIa and Mac-1 were used [94]. While Hageman et al. used CCL17 and CCL22 (G-protein coupled chemokine receptor (CCR4)-specific chemokines) to isolate anti-CCR4 mAbs that were able to antagonize the receptor specific ligands [138]. Indeed, competitive elution strategy is 
valuable when panning on native cell lines, since they are naturally expressing multiple antigens on their surfaces. For example, the human bladder carcinoma cell line T24 expresses different cytokeratins (CKs) such as CK 7, 8 and 18 [139]. A competitive elution using anti-CK8 mAbs (RCK 102) was useful to elute phage binders specific to CK 8 on T4 cell line [140,141]. This method of elution allowed isolation of a large diversity of high affinity phage clones against CK 8, confirmed by their reactivity against CK 8 antigen in ELISA, immunoblotting and immunofluorescence assays [140,141]. Although this method seems feasible and effective, optimising the concentrations and incubation periods of competitive elution agents is critical to achieve the expected outcomes [141].

\section{Conclusions}

Several cell-based panning strategies have been published over the years and, here, we highlighted the differences and the novelty of many of them. There is no cell-based panning protocol which provides a fully optimised "plug and play" scheme that could be translated flawlessly to challenging or different membrane protein systems. The reviewed protocols offer valuable descriptions of the potential pitfalls that pertain to whole cell panning and provide suggestions to overcome several of them. It is clear that whole cell panning is challenging even for membrane proteins with relatively simple structures and large extracellular domains. More complex structures such as multi-pass ion-channels and G-protein coupled receptors present an even greater challenge as they present relatively little exposed epitope to the phage library. Technique optimisations must be done on a case-by-case basis and should focus on ensuring a high display level of correctly-folded target antigen, and removing non-specific binding events.

In brief, phage display is an inexpensive, facile and powerful tool in drug discovery and development that allows isolation of recombinant $\mathrm{mAbs}$ with high specificity against particular antigens in short period of time. There are several FDA approved phage display-derived antibodies and antibody fragments, such as adalimumab, ranibizumab and necitumumab, and many others in clinical trials, such as mavrilimumab and carlumab [142-144]. Many academic institutions and industrial laboratories are continually developing methods for the design, construction and screening of antibody libraries. Further improvements are expected to be achieved in the coming years as this technology contributes significantly toward therapeutic drug discovery. This review article presents several examples of cell-based panning strategies that have been successful for their particular application. However, there has been limited research to optimise the method of cell-based panning. Optimisations aim to improve the presentation of the antigen of interest, to reduce non-specific binding events, to increase the enrichment of desirable binders over those binding irrelevant antigens and to minimize cell loss. Methodology for cell-based panning is still being refined, with many novel techniques being described. A successful cell-based panning campaign is likely to be highly dependent on the antigen of interest, and the methodology needs to be optimised on a case-by-case basis.

Acknowledgments: The authors wish to thank Lyndon Raftery, Neetika Arora, Nadya Panagides and Sumukh Kumble, (AIBN) for their help in editing the manuscript. M.A.A. is academically sponsored by the government of Saudi Arabia to pursue PhD degree in the field of biotechnology.

Author Contributions: M.A.A. conceived the review subject, researched the data and wrote the main manuscript text. M.L.J. provided a substantial contribution to the discussion of content and helped with planning and writing of the article. C.B.H. and S.M.M. helped with reviewing and editing the manuscript text. The manuscript was reviewed by all authors.

Conflicts of Interest: The authors declare no conflict of interest.

\section{References}

1. Bradbury, A.; Pluckthun, A. Reproducibility: Standardize antibodies used in research. Nature 2015, 518, 27-29. [CrossRef] [PubMed]

2. Weiner, G.J. Building better monoclonal antibody-based therapeutics. Nat. Rev. Cancer 2015, 15, 361-370. [CrossRef] [PubMed] 
3. Geng, X.; Kong, X.; Hu, H.; Chen, J.; Yang, F.; Liang, H.; Chen, X.; Hu, Y. Research and development of therapeutic mAbs: An analysis based on pipeline projects. Hum. Vaccin. Immunother. 2015, 11, 2769-2776. [CrossRef] [PubMed]

4. Niwa, R.; Satoh, M. The current status and prospects of antibody engineering for therapeutic use: Focus on glycoengineering technology. J. Pharm. Sci. 2015, 104, 930-941. [CrossRef] [PubMed]

5. Kohler, G.; Milstein, C. Continuous cultures of fused cells secreting antibody of predefined specificity. Nature 1975, 256, 495-497. [CrossRef] [PubMed]

6. Reichert, J.M.; Valge-Archer, V.E. Development trends for monoclonal antibody cancer therapeutics. Nat. Rev. Drug Discov. 2007, 6, 349-356. [CrossRef] [PubMed]

7. Berger, M.; Shankar, V.; Vafai, A. Therapeutic applications of monoclonal antibodies. Am. J. Med. Sci. 2002, 324, 14-30. [CrossRef] [PubMed]

8. Morrison, S.L.; Oi, V.T. Genetically engineered antibody molecules. Adv. Immunol. 1989, 44, 65-92. [PubMed]

9. Studnicka, G.M.; Soares, S.; Better, M.; Williams, R.E.; Nadell, R.; Horwitz, A.H. Human-engineered monoclonal antibodies retain full specific binding activity by preserving non-CDR complementaritymodulating residues. Protein Eng. 1994, 7, 805-814. [CrossRef] [PubMed]

10. Lonberg, N. Human antibodies from transgenic animals. Nat. Biotechnol. 2005, 23, 1117-1125. [CrossRef] [PubMed]

11. Winter, G.; Milstein, C. Man-made antibodies. Nature 1991, 349, 293-299. [CrossRef] [PubMed]

12. Smith, G.P. Filamentous fusion phage: Novel expression vectors that display cloned antigens on the virion surface. Science 1985, 228, 1315-1317. [CrossRef] [PubMed]

13. Tikunova, N.V.; Morozova, V.V. Phage display on the base of filamentous bacteriophages: Application for recombinant antibodies selection. Acta Nat. 2009, 1, 20-28.

14. McCafferty, J.; Griffiths, A.D.; Winter, G.; Chiswell, D.J. Phage antibodies: Filamentous phage displaying antibody variable domains. Nature 1990, 348, 552-554. [CrossRef] [PubMed]

15. Heinis, C.; Rutherford, T.; Freund, S.; Winter, G. Phage-encoded combinatorial chemical libraries based on bicyclic peptides. Nat. Chem. Biol. 2009, 5, 502-507. [CrossRef] [PubMed]

16. Thie, H.; Meyer, T.; Schirrmann, T.; Hust, M.; Dubel, S. Phage display derived therapeutic antibodies. Curr. Pharm. Biotechnol. 2008, 9, 439-446. [CrossRef] [PubMed]

17. Barbas, C.F., 3rd; Kang, A.S.; Lerner, R.A.; Benkovic, S.J. Assembly of combinatorial antibody libraries on phage surfaces: The gene III site. Proc. Natl. Acad. Sci. USA 1991, 88, 7978-7982. [CrossRef] [PubMed]

18. Clackson, T.; Hoogenboom, H.R.; Griffiths, A.D.; Winter, G. Making antibody fragments using phage display libraries. Nature 1991, 352, 624-628. [CrossRef] [PubMed]

19. Blazek, D.; Celer, V. The production and application of single-chain antibody fragments. Folia Microbiol. 2003, 48, 687-698. [CrossRef]

20. Blazek, D.; Celer, V.; Navratilova, I.; Skladal, P. Generation and characterization of single-chain antibody fragments specific against transmembrane envelope glycoprotein gp46 of maedi-visna virus. J. Virol. Methods 2004, 115, 83-92. [CrossRef] [PubMed]

21. Clark, M.A.; Hawkins, N.J.; Papaioannou, A.; Fiddes, R.J.; Ward, R.L. Isolation of human anti-c-erbB-2 Fabs from a lymph node-derived phage display library. Clin. Exp. Immunol. 1997, 109, 166-174. [CrossRef] [PubMed]

22. Rothe, A.; Klimka, A.; Tur, M.K.; Pfitzner, T.; Huhn, M.; Sasse, S.; Mallmann, P.; Engert, A.; Barth, S. Construction of phage display libraries from reactive lymph nodes of breast carcinoma patients and selection for specifically binding human single chain Fv on cell lines. Int. J. Mol. Med. 2004, 14, 729-735. [CrossRef] [PubMed]

23. Nagano, K.; Imai, S.; Mukai, Y.; Nakagawa, S.; Abe, Y.; Kamada, H.; Tsunoda, S.; Tsutsumi, Y. Rapid isolation of intrabody candidates by using an optimized non-immune phage antibody library. Die Pharm. 2009, 64, 238-241.

24. Lowman, H.B.; Bass, S.H.; Simpson, N.; Wells, J.A. Selecting high-affinity binding proteins by monovalent phage display. Biochemistry 1991, 30, 10832-10838. [CrossRef] [PubMed]

25. Bass, S.; Greene, R.; Wells, J.A. Hormone phage: An enrichment method for variant proteins with altered binding properties. Proteins 1990, 8, 309-314. [CrossRef] [PubMed]

26. Sidhu, S.S. Engineering M13 for phage display. Biomol. Eng. 2001, 18, 57-63. [CrossRef]

27. Smith, G.P.; Petrenko, V.A. Phage display. Chem. Rev. 1997, 97, 391-410. [CrossRef] [PubMed] 
28. Boder, E.T.; Wittrup, K.D. Yeast surface display for screening combinatorial polypeptide libraries. Nat. Biotechnol. 1997, 15, 553-557. [CrossRef] [PubMed]

29. Gera, N.; Hussain, M.; Rao, B.M. Protein selection using yeast surface display. Methods 2013, 60, 15-26. [CrossRef] [PubMed]

30. Boder, E.T.; Raeeszadeh-Sarmazdeh, M.; Price, J.V. Engineering antibodies by yeast display. Arch. Biochem. Biophys. 2012, 526, 99-106. [CrossRef] [PubMed]

31. Chao, G.; Lau, W.L.; Hackel, B.J.; Sazinsky, S.L.; Lippow, S.M.; Wittrup, K.D. Isolating and engineering human antibodies using yeast surface display. Nat. Protoc. 2006, 1, 755-768. [CrossRef] [PubMed]

32. Kieke, M.C.; Cho, B.K.; Boder, E.T.; Kranz, D.M.; Wittrup, K.D. Isolation of anti-T cell receptor scFv mutants by yeast surface display. Protein Eng. 1997, 10, 1303-1310. [CrossRef] [PubMed]

33. Feldhaus, M.J.; Siegel, R.W.; Opresko, L.K.; Coleman, J.R.; Feldhaus, J.M.; Yeung, Y.A.; Cochran, J.R.; Heinzelman, P.; Colby, D.; Swers, J.; et al. Flow-cytometric isolation of human antibodies from a nonimmune saccharomyces cerevisiae surface display library. Nat. Biotechnol. 2003, 21, 163-170. [CrossRef] [PubMed]

34. Colby, D.W.; Garg, P.; Holden, T.; Chao, G.; Webster, J.M.; Messer, A.; Ingram, V.M.; Wittrup, K.D. Development of a human light chain variable domain (VL) intracellular antibody specific for the amino terminus of huntingtin via yeast surface display. J. Mol. Biol. 2004, 342, 901-912. [CrossRef] [PubMed]

35. Ho, M.; Pastan, I. Display and selection of scFv antibodies on HEK-293T cells. Methods Mol. Biol. 2009, 562, 99-113. [PubMed]

36. Ho, M.; Pastan, I. Mammalian cell display for antibody engineering. Methods Mol. Biol. 2009, 525, 337-352. [PubMed]

37. Ho, M.; Nagata, S.; Pastan, I. Isolation of anti-CD22 Fv with high affinity by Fv display on human cells. Proc. Natl. Acad. Sci. USA 2006, 103, 9637-9642. [CrossRef] [PubMed]

38. Akamatsu, Y.; Pakabunto, K.; Xu, Z.; Zhang, Y.; Tsurushita, N. Whole IgG surface display on mammalian cells: Application to isolation of neutralizing chicken monoclonal anti-IL-12 antibodies. J. Immunol. Methods 2007, 327, 40-52. [CrossRef] [PubMed]

39. Zhou, C.; Jacobsen, F.W.; Cai, L.; Chen, Q.; Shen, W.D. Development of a novel mammalian cell surface antibody display platform. mAbs 2010, 2, 508-518. [CrossRef] [PubMed]

40. Beerli, R.R.; Bauer, M.; Buser, R.B.; Gwerder, M.; Muntwiler, S.; Maurer, P.; Saudan, P.; Bachmann, M.F. Isolation of human monoclonal antibodies by mammalian cell display. Proc. Natl. Acad. Sci. USA 2008, 105, 14336-14341. [CrossRef] [PubMed]

41. Boeke, J.D.; Model, P. A prokaryotic membrane anchor sequence: Carboxyl terminus of bacteriophage f1 gene III protein retains it in the membrane. Proc. Natl. Acad. Sci. USA 1982, 79, 5200-5204. [CrossRef] [PubMed]

42. Rakonjac, J.; Feng, J.; Model, P. Filamentous phage are released from the bacterial membrane by a two-step mechanism involving a short C-terminal fragment of pIII. J. Mol. Biol. 1999, 289, 1253-1265. [CrossRef] [PubMed]

43. Loeb, T. Isolation of a bacteriophage specific for the F plus and Hfr mating types of escherichia coli K-12. Science 1960, 131, 932-933. [CrossRef] [PubMed]

44. Rakonjac, J.; Bennett, N.J.; Spagnuolo, J.; Gagic, D.; Russel, M. Filamentous bacteriophage: Biology, phage display and nanotechnology applications. Curr. Issues Mol. Biol. 2011, 13, 51-76. [PubMed]

45. Specthrie, L.; Bullitt, E.; Horiuchi, K.; Model, P.; Russel, M.; Makowski, L. Construction of a microphage variant of filamentous bacteriophage. J. Mol. Biol. 1992, 228, 720-724. [CrossRef]

46. Van Wezenbeek, P.M.; Hulsebos, T.J.; Schoenmakers, J.G. Nucleotide sequence of the filamentous bacteriophage M13 DNA genome: Comparison with phage fd. Gene 1980, 11, 129-148. [CrossRef]

47. Sidhu, S.S.; Weiss, G.A.; Wells, J.A. High copy display of large proteins on phage for functional selections. J. Mol. Biol. 2000, 296, 487-495. [CrossRef] [PubMed]

48. Sheehan, J.; Marasco, W.A. Phage and yeast display. Microbiol. Spectr. 2015, 3, AID-0028-2014. [CrossRef] [PubMed]

49. Kehoe, J.W.; Kay, B.K. Filamentous phage display in the new millennium. Chem. Rev. 2005, 105, 4056-4072. [CrossRef] [PubMed]

50. Omidfar, K.; Daneshpour, M. Advances in phage display technology for drug discovery. Expert Opin. Drug Discov. 2015, 10, 651-669. [CrossRef] [PubMed] 
51. Ecker, D.M.; Jones, S.D.; Levine, H.L. The therapeutic monoclonal antibody market. $m A b s$ 2015, 7, 9-14. [CrossRef] [PubMed]

52. Parmley, S.F.; Smith, G.P. Antibody-selectable filamentous fd phage vectors: Affinity purification of target genes. Gene 1988, 73, 305-318. [CrossRef]

53. Vieira, J.; Messing, J. Production of single-stranded plasmid DNA. Methods Enzymol. 1987, 153, 3-11. [PubMed]

54. Marks, J.D.; Hoogenboom, H.R.; Bonnert, T.P.; McCafferty, J.; Griffiths, A.D.; Winter, G. By-passing immunization. Human antibodies from V-gene libraries displayed on phage. J. Mol. Biol. 1991, 222, 581-597. [CrossRef]

55. Winter, G.; Griffiths, A.D.; Hawkins, R.E.; Hoogenboom, H.R. Making antibodies by phage display technology. Annu. Rev. Immunol. 1994, 12, 433-455. [CrossRef] [PubMed]

56. Fellouse, F.A.; Esaki, K.; Birtalan, S.; Raptis, D.; Cancasci, V.J.; Koide, A.; Jhurani, P.; Vasser, M.; Wiesmann, C.; Kossiakoff, A.A.; et al. High-throughput generation of synthetic antibodies from highly functional minimalist phage-displayed libraries. J. Mol. Biol. 2007, 373, 924-940. [CrossRef] [PubMed]

57. Mukherjee, S.; Ura, M.; Hoey, R.J.; Kossiakoff, A.A. A new versatile immobilization tag based on the ultra high affinity and reversibility of the calmodulin-calmodulin binding peptide interaction. J. Mol. Biol. 2015, 427, 2707-2725. [CrossRef] [PubMed]

58. Rader, C.; Barbas, C.F., 3rd. Phage display of combinatorial antibody libraries. Curr. Opin. Biotechnol. 1997, 8, 503-508. [CrossRef]

59. Krogh, A.; Larsson, B.; von Heijne, G.; Sonnhammer, E.L. Predicting transmembrane protein topology with a hidden markov model: Application to complete genomes. J. Mol. Biol. 2001, 305, 567-580. [CrossRef] [PubMed]

60. Arce, J.; Sturgis, J.N.; Duneau, J.P. Dissecting membrane protein architecture: An annotation of structural complexity. Biopolymers 2009, 91, 815-829. [CrossRef] [PubMed]

61. Slamon, D.J.; Godolphin, W.; Jones, L.A.; Holt, J.A.; Wong, S.G.; Keith, D.E.; Levin, W.J.; Stuart, S.G.; Udove, J.; Ullrich, A.; et al. Studies of the HER-2/neu proto-oncogene in human breast and ovarian cancer. Science 1989, 244, 707-712. [CrossRef] [PubMed]

62. Servais, E.L.; Colovos, C.; Rodriguez, L.; Bograd, A.J.; Nitadori, J.; Sima, C.; Rusch, V.W.; Sadelain, M.; Adusumilli, P.S. Mesothelin overexpression promotes mesothelioma cell invasion and MMP-9 secretion in an orthotopic mouse model and in epithelioid pleural mesothelioma patients. Clin. Cancer Res. Off. J. Am. Assoc. Cancer Res. 2012, 18, 2478-2489. [CrossRef] [PubMed]

63. Rask-Andersen, M.; Almen, M.S.; Schioth, H.B. Trends in the exploitation of novel drug targets. Nat. Rev. Drug Discov. 2011, 10, 579-590. [CrossRef] [PubMed]

64. Santos, R.; Ursu, O.; Gaulton, A.; Bento, A.P.; Donadi, R.S.; Bologa, C.G.; Karlsson, A.; Al-Lazikani, B.; Hersey, A.; Oprea, T.I.; et al. A comprehensive map of molecular drug targets. Nat. Rev. Drug Discov. 2016, 16, 19-34. [CrossRef] [PubMed]

65. Ho, M.; Feng, M.; Fisher, R.J.; Rader, C.; Pastan, I. A novel high-affinity human monoclonal antibody to mesothelin. Int. J. Cancer 2011, 128, 2020-2030. [CrossRef] [PubMed]

66. Lu, D.; Shen, J.; Vil, M.D.; Zhang, H.; Jimenez, X.; Bohlen, P.; Witte, L.; Zhu, Z. Tailoring in vitro selection for a picomolar affinity human antibody directed against vascular endothelial growth factor receptor 2 for enhanced neutralizing activity. J. Biol. Chem. 2003, 278, 43496-43507. [CrossRef] [PubMed]

67. Lu, D.; Zhang, H.; Ludwig, D.; Persaud, A.; Jimenez, X.; Burtrum, D.; Balderes, P.; Liu, M.; Bohlen, P.; Witte, L.; et al. Simultaneous blockade of both the epidermal growth factor receptor and the insulin-like growth factor receptor signaling pathways in cancer cells with a fully human recombinant bispecific antibody. J. Biol. Chem. 2004, 279, 2856-2865. [CrossRef] [PubMed]

68. Jones, M.L.; Seldon, T.; Smede, M.; Linville, A.; Chin, D.Y.; Barnard, R.; Mahler, S.M.; Munster, D.; Hart, D.; Gray, P.P.; et al. A method for rapid, ligation-independent reformatting of recombinant monoclonal antibodies. J. Immunol. Methods 2010, 354, 85-90. [CrossRef] [PubMed]

69. Sarkar, C.A.; Dodevski, I.; Kenig, M.; Dudli, S.; Mohr, A.; Hermans, E.; Pluckthun, A. Directed evolution of a G protein-coupled receptor for expression, stability, and binding selectivity. Proc. Natl. Acad. Sci. USA 2008, 105, 14808-14813. [CrossRef] [PubMed]

70. White, S.H.; Wimley, W.C. Membrane protein folding and stability: Physical principles. Annu. Rev. Biophys. Biomol. Struct. 1999, 28, 319-365. [CrossRef] [PubMed] 
71. Butler, J.E.; Navarro, P.; Sun, J. Adsorption-induced antigenic changes and their significance in ELISA and immunological disorders. Immunol. Investig. 1997, 26, 39-54. [CrossRef]

72. Butler, J.E.; Ni, L.; Nessler, R.; Joshi, K.S.; Suter, M.; Rosenberg, B.; Chang, J.; Brown, W.R.; Cantarero, L.A. The physical and functional behavior of capture antibodies adsorbed on polystyrene. J. Immunol. Methods 1992, 150, 77-90. [CrossRef]

73. Nagy, P.; Friedlander, E.; Tanner, M.; Kapanen, A.I.; Carraway, K.L.; Isola, J.; Jovin, T.M. Decreased accessibility and lack of activation of ErbB2 in JIMT-1, a herceptin-resistant, MUC4-expressing breast cancer cell line. Cancer Res. 2005, 65, 473-482. [PubMed]

74. Lipes, B.D.; Chen, Y.H.; Ma, H.; Staats, H.F.; Kenan, D.J.; Gunn, M.D. An entirely cell-based system to generate single-chain antibodies against cell surface receptors. J. Mol. Biol. 2008, 379, 261-272. [CrossRef] [PubMed]

75. Huang, R.; Kiss, M.; Batonick, M.; Weiner, M.; Kay, B. Generating recombinant antibodies to membrane proteins through phage display. Antibodies 2016, 5, 11. [CrossRef]

76. Cattaneo, A. Tanezumab, a recombinant humanized mab against nerve growth factor for the treatment of acute and chronic pain. Curr. Opin. Mol. Ther. 2010, 12, 94-106. [PubMed]

77. Weiner, G.J. Rituximab: Mechanism of action. Semin. Hematol. 2010, 47, 115-123. [CrossRef] [PubMed]

78. Monne, M.; Chan, K.W.; Slotboom, D.J.; Kunji, E.R. Functional expression of eukaryotic membrane proteins in lactococcus lactis. Protein Sci. 2005, 14, 3048-3056. [CrossRef] [PubMed]

79. Siva, A.C.; Kirkland, R.E.; Lin, B.; Maruyama, T.; McWhirter, J.; Yantiri-Wernimont, F.; Bowdish, K.S.; Xin, H. Selection of anti-cancer antibodies from combinatorial libraries by whole-cell panning and stringent subtraction with human blood cells. J. Immunol. Methods 2008, 330, 109-119. [CrossRef] [PubMed]

80. Krag, D.N.; Shukla, G.S.; Shen, G.P.; Pero, S.; Ashikaga, T.; Fuller, S.; Weaver, D.L.; Burdette-Radoux, S.; Thomas, C. Selection of tumor-binding ligands in cancer patients with phage display libraries. Cancer Res. 2006, 66, 7724-7733. [CrossRef] [PubMed]

81. Dantas-Barbosa, C.; de Macedo Brigido, M.; Maranhao, A.Q. Antibody phage display libraries: Contributions to oncology. Int. J. Mol. Sci. 2012, 13, 5420-5440. [CrossRef] [PubMed]

82. Zhao, L.; Qu, L.; Zhou, J.; Sun, Z.; Zou, H.; Chen, Y.Y.; Marks, J.D.; Zhou, Y. High throughput identification of monoclonal antibodies to membrane bound and secreted proteins using yeast and phage display. PLoS ONE 2014, 9, e111339. [CrossRef] [PubMed]

83. Zhou, Y.; Zou, H.; Zhang, S.; Marks, J.D. Internalizing cancer antibodies from phage libraries selected on tumor cells and yeast-displayed tumor antigens. J. Mol. Biol. 2010, 404, 88-99. [CrossRef] [PubMed]

84. Gorden, B.H.; Kim, J.H.; Sarver, A.L.; Frantz, A.M.; Breen, M.; Lindblad-Toh, K.; O’Brien, T.D.; Sharkey, L.C.; Modiano, J.F.; Dickerson, E.B. Identification of three molecular and functional subtypes in canine hemangiosarcoma through gene expression profiling and progenitor cell characterization. Am. J. Pathol. 2014, 184, 985-995. [CrossRef] [PubMed]

85. Yoon, H.; Song, J.M.; Ryu, C.J.; Kim, Y.G.; Lee, E.K.; Kang, S.; Kim, S.J. An efficient strategy for cell-based antibody library selection using an integrated vector system. BMC Biotechnol. 2012, 12, 62. [CrossRef] [PubMed]

86. Yuan, Q.A.; Robinson, M.K.; Simmons, H.H.; Russeva, M.; Adams, G.P. Isolation of anti-MISIIR scFv molecules from a phage display library by cell sorter biopanning. Cancer Immunol. Immunother. 2008, 57, 367-378. [CrossRef] [PubMed]

87. Jones, M.L.; Alfaleh, M.A.; Kumble, S.; Zhang, S.; Osborne, G.W.; Yeh, M.; Arora, N.; Hou, J.J.; Howard, C.B.; Chin, D.Y.; et al. Targeting membrane proteins for antibody discovery using phage display. Sci. Rep. 2016, 6, 26240. [CrossRef] [PubMed]

88. Xu, M.Y.; Xu, X.H.; Chen, G.Z.; Deng, X.L.; Li, J.; Yu, X.J.; Chen, M.Z. Production of a human single-chain variable fragment antibody against esophageal carcinoma. World J. Gastroenterol:: WJG 2004, 10, 2619-2623. [CrossRef] [PubMed]

89. Cai, X.; Garen, A. Anti-melanoma antibodies from melanoma patients immunized with genetically modified autologous tumor cells: Selection of specific antibodies from single-chain Fv fusion phage libraries. Proc. Natl. Acad. Sci. USA 1995, 92, 6537-6541. [CrossRef] [PubMed]

90. Shen, Y.; Yang, X.; Dong, N.; Xie, X.; Bai, X.; Shi, Y. Generation and selection of immunized Fab phage display library against human B cell lymphoma. Cell Res. 2007, 17, 650-660. [CrossRef] [PubMed] 
91. Ridgway, J.B.; Ng, E.; Kern, J.A.; Lee, J.; Brush, J.; Goddard, A.; Carter, P. Identification of a human anti-CD55 single-chain Fv by subtractive panning of a phage library using tumor and nontumor cell lines. Cancer Res. 1999, 59, 2718-2723. [PubMed]

92. Keller, T.; Kalt, R.; Raab, I.; Schachner, H.; Mayrhofer, C.; Kerjaschki, D.; Hantusch, B. Selection of scFv antibody fragments binding to human blood versus lymphatic endothelial surface antigens by direct cell phage display. PLoS ONE 2015, 10, e0127169. [CrossRef] [PubMed]

93. Hoogenboom, H.R.; Lutgerink, J.T.; Pelsers, M.M.; Rousch, M.J.; Coote, J.; Van Neer, N.; De Bruine, A.; Van Nieuwenhoven, F.A.; Glatz, J.F.; Arends, J.W. Selection-dominant and nonaccessible epitopes on cell-surface receptors revealed by cell-panning with a large phage antibody library. Eur. J. Biochem. 1999, 260, 774-784. [CrossRef] [PubMed]

94. Eisenhardt, S.U.; Schwarz, M.; Bassler, N.; Peter, K. Subtractive single-chain antibody (scFv) phage-display: Tailoring phage-display for high specificity against function-specific conformations of cell membrane molecules. Nat. Protoc. 2007, 2, 3063-3073. [CrossRef] [PubMed]

95. Schwarz, M.; Rottgen, P.; Takada, Y.; Le Gall, F.; Knackmuss, S.; Bassler, N.; Buttner, C.; Little, M.; Bode, C.; Peter, K. Single-chain antibodies for the conformation-specific blockade of activated platelet integrin $\alpha_{\mathrm{IIb}} \beta_{3}$ designed by subtractive selection from naive human phage libraries. FASEB J.: Off. Publ. Fed. Am. Soc. Exp. Biol. 2004, 18, 1704-1706.

96. Schwarz, M.; Meade, G.; Stoll, P.; Ylanne, J.; Bassler, N.; Chen, Y.C.; Hagemeyer, C.E.; Ahrens, I.; Moran, N.; Kenny, D.; et al. Conformation-specific blockade of the integrin GPIIb/IIIa: A novel antiplatelet strategy that selectively targets activated platelets. Circ. Res. 2006, 99, 25-33. [CrossRef] [PubMed]

97. Eisenhardt, S.U.; Schwarz, M.; Schallner, N.; Soosairajah, J.; Bassler, N.; Huang, D.; Bode, C.; Peter, K. Generation of activation-specific human anti-alphambeta2 single-chain antibodies as potential diagnostic tools and therapeutic agents. Blood 2007, 109, 3521-3528. [CrossRef] [PubMed]

98. Wang, J.; Liu, Y.; Teesalu, T.; Sugahara, K.N.; Kotamrajua, V.R.; Adams, J.D.; Ferguson, B.S.; Gong, Q.; Oh, S.S.; Csordas, A.T.; et al. Selection of phage-displayed peptides on live adherent cells in microfluidic channels. Proc. Natl. Acad. Sci. USA 2011, 108, 6909-6914. [CrossRef] [PubMed]

99. Dorfmueller, S.; Tan, H.C.; Ngoh, Z.X.; Toh, K.Y.; Peh, G.; Ang, H.P.; Seah, X.Y.; Chin, A.; Choo, A.; Mehta, J.S.; et al. Isolation of a recombinant antibody specific for a surface marker of the corneal endothelium by phage display. Sci. Rep. 2016, 6, 21661. [CrossRef] [PubMed]

100. Persson, J.; Augustsson, P.; Laurell, T.; Ohlin, M. Acoustic microfluidic chip technology to facilitate automation of phage display selection. FEBS J. 2008, 275, 5657-5666. [CrossRef] [PubMed]

101. Levitan, B. Stochastic modeling and optimization of phage display. J. Mol. Biol. 1998, 277, 893-916. [CrossRef] [PubMed]

102. Warrick, J.; Meyvantsson, I.; Ju, J.; Beebe, D.J. High-throughput microfluidics: Improved sample treatment and washing over standard wells. Lab Chip 2007, 7, 316-321. [CrossRef] [PubMed]

103. Fisher, A.B.; Chien, S.; Barakat, A.I.; Nerem, R.M. Endothelial cellular response to altered shear stress. Am. J. Physiol. Lung Cell. Mol. Physiol. 2001, 281, L529-L533. [PubMed]

104. Nagel, T.; Resnick, N.; Atkinson, W.J.; Dewey, C.F., Jr.; Gimbrone, M.A., Jr. Shear stress selectively upregulates intercellular adhesion molecule-1 expression in cultured human vascular endothelial cells. J. Clin. Investig. 1994, 94, 885-891. [CrossRef] [PubMed]

105. Sorensen, M.D.; Agerholm, I.E.; Christensen, B.; Kolvraa, S.; Kristensen, P. Microselection-affinity selecting antibodies against a single rare cell in a heterogeneous population. J. Cell. Mol. Med. 2010, 14, 1953-1961. [CrossRef] [PubMed]

106. Sorensen, M.D.; Kristensen, P. Selection of antibodies against a single rare cell present in a heterogeneous population using phage display. Nat. Protoc. 2011, 6, 509-522. [CrossRef] [PubMed]

107. Ross, A.A.; Cooper, B.W.; Lazarus, H.M.; Mackay, W.; Moss, T.J.; Ciobanu, N.; Tallman, M.S.; Kennedy, M.J.; Davidson, N.E.; Sweet, D.; et al. Detection and viability of tumor cells in peripheral blood stem cell collections from breast cancer patients using immunocytochemical and clonogenic assay techniques. Blood 1993, 82, 2605-2610. [PubMed]

108. Sanchez-Martin, D.; Sorensen, M.D.; Lykkemark, S.; Sanz, L.; Kristensen, P.; Ruoslahti, E.; Alvarez-Vallina, L. Selection strategies for anticancer antibody discovery: Searching off the beaten path. Trends Biotechnol. 2015, 33, 292-301. [CrossRef] [PubMed]

109. Patel, Y.C.; Srikant, C.B. Somatostatin receptors. Trends Endocrinol. Metab.: TEM 1997, 8, 398-405. [CrossRef] 
110. Daviet, L.; Buckland, R.; Puente Navazo, M.D.; McGregor, J.L. Identification of an immunodominant functional domain on human cd36 antigen using human-mouse chimaeric proteins and homologuereplacement mutagenesis. Biochem. J. 1995, 305 Pt 1, 221-224. [CrossRef] [PubMed]

111. Shen, W.; Li, S.; Park, M.-K.; Zhang, Z.; Cheng, Z.; Petrenko, V.A.; Chin, B.A. Blocking agent optimization for nonspecific binding on phage based magnetoelastic biosensors. J. Electrochem. Soc. 2012, 159, B818-B823. [CrossRef]

112. Menendez, A.; Scott, J.K. The nature of target-unrelated peptides recovered in the screening of phage-displayed random peptide libraries with antibodies. Anal. Biochem. 2005, 336, 145-157. [CrossRef] [PubMed]

113. Heitner, T.; Moor, A.; Garrison, J.L.; Marks, C.; Hasan, T.; Marks, J.D. Selection of cell binding and internalizing epidermal growth factor receptor antibodies from a phage display library. J. Immunol. Methods 2001, 248, 17-30. [CrossRef]

114. Watters, J.M.; Telleman, P.; Junghans, R.P. An optimized method for cell-based phage display panning. Immunotechnol.: Int. J.Immunol. Eng. 1997, 3, 21-29. [CrossRef]

115. Poul, M.A.; Becerril, B.; Nielsen, U.B.; Morisson, P.; Marks, J.D. Selection of tumor-specific internalizing human antibodies from phage libraries. J. Mol. Biol. 2000, 301, 1149-1161. [CrossRef] [PubMed]

116. Andersen, P.S.; Stryhn, A.; Hansen, B.E.; Fugger, L.; Engberg, J.; Buus, S. A recombinant antibody with the antigen-specific, major histocompatibility complex-restricted specificity of T cells. Proc. Natl. Acad. Sci. USA 1996, 93, 1820-1824. [CrossRef] [PubMed]

117. De Kruif, J.; Terstappen, L.; Boel, E.; Logtenberg, T. Rapid selection of cell subpopulation-specific human monoclonal antibodies from a synthetic phage antibody library. Proc. Natl. Acad. Sci. USA 1995, 92, 3938-3942. [CrossRef] [PubMed]

118. Pavoni, E.; Vaccaro, P.; Anastasi, A.M.; Minenkova, O. Optimized selection of anti-tumor recombinant antibodies from phage libraries on intact cells. Mol. Immunol. 2014, 57, 317-322. [CrossRef] [PubMed]

119. Koopman, G.; Reutelingsperger, C.P.; Kuijten, G.A.; Keehnen, R.M.; Pals, S.T.; van Oers, M.H. Annexin V for flow cytometric detection of phosphatidylserine expression on B cells undergoing apoptosis. Blood 1994, 84, 1415-1420. [PubMed]

120. Neurauter, A.A.; Bonyhadi, M.; Lien, E.; Nokleby, L.; Ruud, E.; Camacho, S.; Aarvak, T. Cell isolation and expansion using dynabeads®. Adv. Biochem. Eng. Biot. 2007, 106, 41-73.

121. Jain, J.; Veggiani, G.; Howarth, M. Cholesterol loading and ultrastable protein interactions determine the level of tumor marker required for optimal isolation of cancer cells. Cancer Res. 2013, 73, 2310-2321. [CrossRef] [PubMed]

122. Berdichevsky, Y.; Ben-Zeev, E.; Lamed, R.; Benhar, I. Phage display of a cellulose binding domain from clostridium thermocellum and its application as a tool for antibody engineering. J. Immunol. Methods 1999, 228, 151-162. [CrossRef]

123. Dziegiel, M.; Nielsen, L.K.; Andersen, P.S.; Blancher, A.; Dickmeiss, E.; Engberg, J. Phage display used for gene cloning of human recombinant antibody against the erythrocyte surface antigen, rhesus D. J. Immunol. Methods 1995, 182, 7-19. [CrossRef]

124. Tur, M.K.; Huhn, M.; Sasse, S.; Engert, A.; Barth, S. Selection of scfv phages on intact cells under low pH conditions leads to a significant loss of insert-free phages. Biotechniques 2001, 30, 404-413. [PubMed]

125. Mohan, K.; Weiss, G.A. Engineering chemically modified viruses for prostate cancer cell recognition. Mol. Biosyst. 2015, 11, 3264-3272. [CrossRef] [PubMed]

126. Giordano, R.J.; Cardo-Vila, M.; Lahdenranta, J.; Pasqualini, R.; Arap, W. Biopanning and rapid analysis of selective interactive ligands. Nat. Med. 2001, 7, 1249-1253. [CrossRef] [PubMed]

127. Carneiro, A.P.; Reis, C.F.; Morari, E.C.; Maia, Y.C.; Nascimento, R.; Bonatto, J.M.; de Souza, M.A.; Goulart, L.R.; Ward, L.S. A putative OTU domain-containing protein 1 deubiquitinating enzyme is differentially expressed in thyroid cancer and identifies less-aggressive tumours. Br. J. Cancer 2014, 111, 551-558. [CrossRef] [PubMed]

128. Gerstenbruch, S.; Brooks, C.L.; Kosma, P.; Brade, L.; Mackenzie, C.R.; Evans, S.V.; Brade, H.; Muller-Loennies, S. Analysis of cross-reactive and specific anti-carbohydrate antibodies against lipopolysaccharide from Chlamydophila psittaci. Glycobiology 2010, 20, 461-472. [CrossRef] [PubMed]

129. Silverstein, S.C.; Steinman, R.M.; Cohn, Z.A. Endocytosis. Annu. Rev. Biochem. 1977, 46, 669-722. [CrossRef] [PubMed] 
130. Fitting, J.; Blume, T.; Ten Haaf, A.; Blau, W.; Gattenlohner, S.; Tur, M.K.; Barth, S. Phage display-based generation of novel internalizing antibody fragments for immunotoxin-based treatment of acute myeloid leukemia. $m A$ bs 2015, 7, 390-402. [CrossRef] [PubMed]

131. Becerril, B.; Poul, M.A.; Marks, J.D. Toward selection of internalizing antibodies from phage libraries. Biochem. Biophys. Res. Commun. 1999, 255, 386-393. [CrossRef] [PubMed]

132. Ohkuma, S.; Poole, B. Fluorescence probe measurement of the intralysosomal $\mathrm{pH}$ in living cells and the perturbation of $\mathrm{pH}$ by various agents. Proc. Natl. Acad. Sci. USA 1978, 75, 3327-3331. [CrossRef] [PubMed]

133. Hilderbrand, S.A.; Kelly, K.A.; Niedre, M.; Weissleder, R. Near infrared fluorescence-based bacteriophage particles for ratiometric pH imaging. Bioconj. Chem. 2008, 19, 1635-1639. [CrossRef] [PubMed]

134. Gillies, R.J.; Raghunand, N.; Garcia-Martin, M.L.; Gatenby, R.A. pH imaging. A review of ph measurement methods and applications in cancers. IEEE Eng. Med. Biol. Mag.:Quart. Mag. Eng. Med. Biol. Soc. 2004, 23, 57-64. [CrossRef]

135. Laakkonen, P.; Porkka, K.; Hoffman, J.A.; Ruoslahti, E. A tumor-homing peptide with a targeting specificity related to lymphatic vessels. Nat. Med. 2002, 8, 751-755. [CrossRef] [PubMed]

136. Michon, I.N.; Hauer, A.D.; von der Thusen, J.H.; Molenaar, T.J.; van Berkel, T.J.; Biessen, E.A.; Kuiper, J. Targeting of peptides to restenotic vascular smooth muscle cells using phage display in vitro and in vivo. Biochim. Biophys. Acta. 2002, 1591, 87-97. [CrossRef]

137. Rangel, R.; Dobroff, A.S.; Guzman-Rojas, L.; Salmeron, C.C.; Gelovani, J.G.; Sidman, R.L.; Pasqualini, R.; Arap, W. Targeting mammalian organelles with internalizing phage (iPhage) libraries. Nat. Protoc. 2013, 8 , 1916-1939. [CrossRef] [PubMed]

138. Hagemann, U.B.; Gunnarsson, L.; Geraudie, S.; Scheffler, U.; Griep, R.A.; Reiersen, H.; Duncan, A.R.; Kiprijanov, S.M. Fully human antagonistic antibodies against CCR4 potently inhibit cell signaling and chemotaxis. PLoS ONE 2014, 9, e103776. [CrossRef] [PubMed]

139. Schaafsma, H.E.; Ramaekers, F.C.; van Muijen, G.N.; Ooms, E.C.; Ruiter, D.J. Distribution of cytokeratin polypeptides in epithelia of the adult human urinary tract. Histochemistry 1989, 91, 151-159. [CrossRef] [PubMed]

140. Meulemans, E.V.; Slobbe, R.; Wasterval, P.; Ramaekers, F.C.; van Eys, G.J. Selection of phage-displayed antibodies specific for a cytoskeletal antigen by competitive elution with a monoclonal antibody. J. Mol. Biol. 1994, 244, 353-360. [CrossRef] [PubMed]

141. Meulemans, E.V.; Nieland, L.J.; Debie, W.H.; Ramaekers, F.C.; van Eys, G.J. Phage displayed antibodies specific for a cytoskeletal antigen. Selection by competitive elution with a monoclonal antibody. Hum. Antib. Hybrid. 1995, 6, 113-118. [CrossRef] [PubMed]

142. Helwick, C. Will necitumumab be cost-effective? Am. Health Drug Benefits 2015, 8, 11. [PubMed]

143. Nixon, A.E.; Sexton, D.J.; Ladner, R.C. Drugs derived from phage display: From candidate identification to clinical practice. $m A$ bs 2014, 6, 73-85. [CrossRef] [PubMed]

144. Frenzel, A.; Schirrmann, T.; Hust, M. Phage display-derived human antibodies in clinical development and therapy. $m A$ bs 2016, 8, 1177-1194. [CrossRef] [PubMed]

(C) 2017 by the authors. Licensee MDPI, Basel, Switzerland. This article is an open access article distributed under the terms and conditions of the Creative Commons Attribution (CC BY) license (http:/ / creativecommons.org/licenses/by/4.0/). 